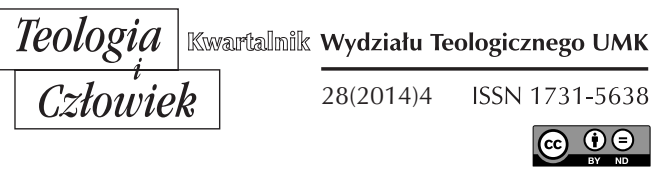

KS. LESŁAW KRZYŻAK*

ŻOŁYNIA

\title{
PIELGRZYMKI W DOKUMENTACH I LITURGIl KOŚCIOŁA
}

DOI: http://dx.doi.org/10.12775/TiCz.2014.061

Pielgrzymki, znane wszystkim ludom i narodom, są istotnym elementem pobożności polskiej. W XXI wieku obserwuje się ich znaczny wzrost. Stają się one spotkaniem z Bogiem, ale też, ze względu na szalone tempo życia, swoistą terapią duchową, czasem wewnętrznego skupienia i odreagowania trudów codzienności oraz doskonałym sposobem chrześcijańskiej formacji. „Pielgrzymowanie to nie wycieczka, to nie turystyka, to akt religijny. Do trudu pieszej wędrówki dochodzą intencja i modlitwa [...]. Trud pielgrzymowania pieszego należy więc do najpiękniejszych i najcenniejszych"1 - napisał ksiądz Ireneusz Skubiś.

Interesujący wydaje się więc temat „obecności” pielgrzymowania w dokumentach, a zwłaszcza w liturgii Kościoła.

W księgach liturgicznych, jakimi są mszały: rzymski, maryjny i franciszkański, nie uwzględnia się pielgrzymki jako uroczystości kościelnej. Nie ma o niej wzmianki ani w święta nakazane, ani też $\mathrm{w}$ dni powszednie. Nie przewiduje się w nich specjalnych modlitw i rytuałów w momencie wyjścia pielgrzymów w trasę, powrotu do domu czy w trakcie trwania piel-

* Ks. Lesław Krzyżak prezbiter archidiecezji przemyskiej, doktor teologii.

1 A. Cichowłazińska, Uchwycić w kadrze pątniczego ducha, "Niedziela" 2013, nr 44 , s. 50 . 
grzymki. A przecież, słusznie uważa się, że mszał jest księgą życia chrześcijańskiego ${ }^{2}$, toteż wszystkie ważniejsze jego aspekty powinny się w nim zawierać.

Mszat rzymski przewiduje tylko sprawowanie liturgii, dostosowanej do potrzeb grup specjalnych. Do takich można zaliczyć pielgrzymów: wspólnotę jednoczącą ludzi ochrzczonych (wierzących), którzy pragną się dzielić miłością, rozwijać wiarę i żyć nadzieją. Spotykają się oni na liturgii, która ich łączy, i tworzą „małe wspólnoty liturgiczne”. Chodzi o to, żeby $\mathrm{w}$ niej zaspokoić szczególne potrzeby tych wiernych i pogłębić ich życie chrześcijańskie, zgodnie z potrzebami i formacją osób tworzących daną grupę. Wykorzystuje się wówczas wszystkie dobrodziejstwa, jakie wypływają z tego szczególnego związku duchowego lub apostolskiego oraz z dążności do wzajemnego budowania się.

Instrukcja De Missis pro coetibus particuralibus ${ }^{3}$, wydana przez Kongregację Kultu Bożego w 1969 roku, szczegółowo charakteryzuje "grupę specjalną", podpowiadając, kogo do niej należy zaliczyć. Między innymi wymienia wspólnoty pielgrzymkowe ${ }^{4}$. Wprawdzie ich członkowie często są sobie obcy, ale liturgia stanowi łączącą ich więź. Omawiany dokument stwierdza, że decyzja, co dla danej grupy jest bardziej odpowiednie: sprawowanie Eucharystii czy inne nabożeństwo, należy do duszpasterza.

Ksiądz Zbigniew Wit, tak jak i wielu mu podobnych znawców problemu, opowiada się po stronie Eucharystii. Uważa, że „podczas liturgii, a szczególnie Mszy świętej, urzeczywistnia się Kościół i ukazuje się więź z Chrystusem, dlatego nie należy z niej rezygnować, gdyż grupy specjalne stanowią wówczas «małe Kościoły» i duszpasterze mogą uwzględniać wtedy potrzeby tych wiernych i skuteczniej kierować formacją poszczególnych jednostek" ${ }^{\prime \prime}$.

Oczywiście, istnieją pewne wymogi, dotyczące także tego typu celebracji mszalnej: jej miejscem powinno być miejsce święte; kościół lub kaplica. Inne (dom prywatny lub instytucja) wymaga specjalnego zezwolenia kompetentnej władzy kościelnej. Eucharystia musi być odpowiednio

${ }^{2}$ Mszał księga życia chrześcijańskiego, red. B. Nadolski, Poznań 1989.

${ }^{3}$ E. Sztafrowski, Podręcznik prawa kanonicznego, t. 3, Warszawa 1986, s. 152-165.

${ }^{4}$ L. Balter, Zgromadzenia liturgiczne matych wspólnot, w: W stużbie Ludowi Bożemu, red. B. Bejze, Poznań 1983, s. 481.

${ }^{5}$ Z. Wit, Msza święta w grupach specjalnych, w: Mszat ksiegga życia chrześcijańskiego, red. B. Nadolski, Poznań 1989, s. 455. 
przygotowana, tak by zachować i wyrabiać w jej uczestnikach poczucie sacrum. Msze dla grup specjalnych z zasady należy odprawiać w dni powszednie, a w niedzielę i inne uroczystości powinny się one włączać w ogólny porządek nabożeństw. Żadnej Eucharystii nie można bowiem uważać za czynność własną zebrania partykularnego, ponieważ zawsze pozostaje ona czynnością Kościoła.

Celebrację należy dostosować do „okoliczności, rzeczy i osób”, toteż celebrans podczas sprawowania Mszy Świętej w jej porządku może dokonać pewnych interwencji. Wolno mu sformułować: wprowadzenia, zakończenia oraz wezwania do trzeciej formuły aktu pokuty. W Mszale rzymskim napisano: „W Mszach świętych odprawianych dla grup specjalnych wolno kapłanowi dobrać teksty bardziej odpowiadające temu szczególnemu sposobowi odprawiania - pod warunkiem jednak, że zostaną one dobrane spośród tekstów zawartych w zatwierdzonym lekcjonarzu". Instrukcja o mszach dla grup specjalnych zaleca też, by ze śpiewu sakralnego „usunąć to wszystko, co by nie odpowiadało świętości obrzędu i nie podtrzymywało pobożności wiernych" ${ }^{\prime \prime}$.

Pielgrzymki, będąc powszechną formą religijności, są jednak typowym wyrazem religijności ludowej. Kościół, świadomy zgodności między nauczaniem Chrystusa a duchowymi wartościami pielgrzymowania, nie tylko tę uznaną formę pobożności zachował, ale też przez całe wieki do niej zachęcał i zachęca nadal. Zwraca też uwagę na to, by pobożność i religijność ludowa (w tym także pielgrzymowanie) były pielęgnowane i formowane $\mathrm{w}$ zgodzie $\mathrm{z}$ liturgią.

Papież Paweł VI w adhortacji apostolskiej Evangelii nuntiandi (O ewangelizacji w świecie wspótczesnym) podkreślił wagę tej ludowej religijności. W jego ujęciu jest ona zbiorem wartości, w duchu mądrości chrześcijańskiej odpowiadających na podstawowe pytania egzystencjalne. Odznacza się zdolnością tworzenia życiowej syntezy. Prowadzi do twórczego połączenia elementu Bożego i ludzkiego, ducha i ciała, rozumu i uczucia7.

Do tego zagadnienia odniósł się też Jan Paweł II. W adhortacji apostolskiej Catechesi tradendae (O katechizacji w naszych czasach) przypomniał, że „praktykowanie tych form pobożności podlega trosce i osądowi biskupów oraz ogólnym normom Kościoła"s.

${ }^{6}$ E. Sztafrowski, Podręcznik prawa kanonicznego..., t. 3, s. 154-165.

${ }^{7}$ http://www.opoka.org.pl/biblioteka/W/WP/pawel_vi/adhortacje/evangelii_ nuntiandi.html [dostęp z dnia 16.12. 2013].

${ }^{8}$ http://www.opoka.org.pl/biblioteka/W/WP/jan_pawel_ii/adhortacje/catechesi.html [dostęp z dnia 16.12. 2013]. 
Także Katechizm Kościota Katolickiego, wśród form pobożności wiernych i religijności ludowej, wymienia cześć oddawaną relikwiom, nawiedzanie sanktuarium i pielgrzymki ${ }^{9}$. Za Konstytucją o liturgii świętej stwierdza, że "te formy pobożności są kontynuacją życia liturgicznego Kościoła, ale go nie zastępują"10. W Konstytucji o liturgii świętej Sobór Watykański II zaleca, by je "tak uporządkować, aby zgadzały się z liturgia, z niej poniekąd wypływały i do niej wiernych prowadziły, ponieważ ona ze swej natury znacznie je przewyższa"11. Zwraca uwagę na to, aby podtrzymywać i wspierać religijność ludową, a w razie potrzeby oczyszczać i pogłębiać zmysł religijny, w tym konieczne jest rozeznanie duszpasterskie.

Podobnie temat pielgrzymek ujmuje Kompendium Katechizmu Kościoła Katolickiego. Też jako odmianę pobożności ludowej, towarzyszącą życiu sakramentalnemu, i umieszcza je wśród „innych celebracji liturgicznych”. Podkreśla, że „Kościół popiera i oświeca światłem wiary autentyczne formy pobożności ludowej"12.

Pozytywne rezultaty pielgrzymki i duchowe owoce, których się po niej oczekuje, zależą między innymi od zapewnienia porządku celebracji i odpowiedniego podkreślenia jej poszczególnych etapów. Dyrektorium o pobożności ludowej i liturgii informuje, że „wyjściu pielgrzymki powinna towarzyszyć modlitwa w kościele parafialnym lub w innej, bardziej odpowiedniej świątyni"13. Może ona polegać na sprawowaniu Eucharystii lub jakiejś części Liturgii godzin i zawierać specjalne błogosławieństwo pielgrzymów. Czasem szczególnie intensywnej modlitwy powinien być ostatni etap pątniczej drogi. Poleca się, aby przebyć go pieszo i procesjonalnie, modląc się, śpiewając i zatrzymując przed znajdującymi się na nim kapliczkami. Przyjęcie pielgrzymów w sanktuarium może mieć charakter pewnego rodzaju „liturgii przekroczenia progu"14. Pobyt w docelowym miejscu pielgrzymki ma stanowić jej punkt kulminacyjny; być czasem nawrócenia, ukoronowanym sakramentem pokuty, czasem szczególnych form modlitwy, takich jak dziękczynienie, błaganie czy prośba o wsta-

\footnotetext{
${ }^{9}$ Katechizm Kościoła Katolickiego, Poznań 1994, s. 395-396, nr 1674.

${ }^{10}$ http:/ / www.dso.diecezja.rzeszow.pl/files/Konstytucja-o-liturgii--witej_8f0x9848.pdf, s. 5 [dostęp z dnia16.12. 2013].

11 Sobór Watykański II. Konstytucje, dekrety, deklaracje, Poznań 1967, s. 49.

${ }_{12}$ Kompendium Katechizmu Kościoła Katolickiego, Kielce 2005, s. 115, nr 353.

${ }^{13}$ Dyrektorium o pobożności ludowej i liturgii. Zasady i wskazania, Poznań 2003, s. 203.

14 Tamże, s. 204.
} 
wiennictwo. Punktem szczytowym pielgrzymki powinna stać się celebracja Eucharystii. Zakończenie należy podsumować odpowiednią modlitwą w sanktuarium lub w kościele, z którego pielgrzymka wyruszyła. Należy zadbać o to, by przedmioty, obrazki, książki („pamiątki z pielgrzymki”) stanowiły przekaz prawdziwego ducha miejsca świętego ${ }^{15}$.

Wśród sakramentaliów, ustanowionych przez Kościół dla uświęcenia pewnych posług, stanów i okoliczności życia chrześcijańskiego, a także użytkowania rzeczy potrzebnych człowiekowi, na pierwszym miejscu znajdują się błogosławieństwa. Jak podaje Katechizm Kościoła Katolickiego: „Każde błogosławieństwo jest uwielbieniem Boga i modlitwą o Jego dary. W Chrystusie chrześcijanie są błogosławieni przez Boga Ojca «wszelkim błogosławieństwem duchowym» (Ef 1,3). Dlatego Kościół udziela błogosławieństwa, wzywając imienia Jezusa i czyniąc zazwyczaj święty znak krzyża Chrystusa"16. Ściśle łączą się one z pielgrzymkami.

Do pielgrzymek odnoszą się Agendy liturgiczne, będące zbiorem modlitw, nabożeństw i błogosławieństw, przydatnych w sprawowaniu liturgii i nabożeństw pozaliturgicznych w ciągu całego roku liturgicznego. Podpowiadają celebracje związane $\mathrm{z}$ ich rozpoczęciem i zakończeniem. W agendzie tarnowskiej czytamy: „Przed wyruszeniem pielgrzymki, pielgrzymi gromadzą się $\mathrm{w}$ świątyni parafialnej lub - w przypadku zbyt licznej grupy - na placu przykościelnym. Proboszcz ubrany w komżę i stułę staje przed pielgrzymami i błogosławi pielgrzymów, zachowując ryt podany w Obrzędach btogostawieństw" ${ }^{\prime \prime 17}$. Podobne celebracje proponuje się po powrocie z pielgrzymki. Po pokropieniu wodą święconą, pątnicy wchodzą do kościoła. Następuje błogosławieństwo, które jest podziękowaniem Opatrzności Bożej za wszystkie łaski udzielone podczas jej trwania, za szczęśliwy powrót, a także wypraszaniem trwałości owoców pielgrzymki. Celebrans udziela błogosławieństwa według rytu zaproponowanego we wspomnianej wyżej księdze.

Bardziej szczegółowe propozycje nabożeństwa okolicznościowego, związanego z pielgrzymką parafialną, zawarte są w podręczniku Stużba $B o \dot{z} a^{18}$. Na rozpoczęcie pielgrzymki zaleca się celebrację składającą się z pieśni wstępnej (do wyboru spośród: Błogosław, Panie nas; Idźmy, tulmy

\footnotetext{
15 Tamże.

${ }^{16}$ Katechizm Kościoła Katolickiego, s. 395.

17 Agenda liturgiczna Diecezji Tarnowskiej, Tarnów 2002, s. 375.

${ }_{18}$ W. Głowa, Stużba Boża, Lubaczów 1986, s. 787-789.
} 
się jak dziatki lub Gwiazdo śliczna wspaniała), wprowadzenia, modlitw, pieśni Kto się w opiekę, błogosławieństwa i pieśni Jest droga, która wiedzie nas. Według podręcznika po powrocie pielgrzymi powinni zostać pokropieni wodą święconą i wejść do świątyni. Tu proponuje się odśpiewanie pieśni (jednej z zaproponowanych: Cóż Ci, Jezu, damy; Pobłogosław Jezu drogi lub Matko niebieskiego Pana), powitanie pątników przez kapłana, ewentualne nabożeństwo eucharystyczne, odśpiewanie pieśni: Kłaniam się Tobie, modlitwę (po chwili adoracji), błogosławieństwo sakramentalne i pieśń końcową (Na wszystkich drogach życia lub My chcemy Boga).

W Agendzie liturgicznej, opracowanej przez Międzydiecezjalną Komisję ds. Duszpasterstwa Liturgicznego i Muzyki Kościelnej (dla diecezji opolskiej i gliwickiej), wśród nabożeństw okolicznościowych znajdują się nabożeństwa polecane na rozpoczęcie i zakończenie pielgrzymki. We wprowadzeniu zamieszczono wyjaśnienie, że „Kościół jest Ludem Bożym pielgrzymującym do domu Ojca. Obrazem tego są nasze pielgrzymki i dni modlitw w naszych miejscach pielgrzymkowych"19.

Tak zaproponowana celebracja nabożeństwa różni się od innych pieśni zalecanych na rozpoczęcie i zakończenie pielgrzymki. Na początek proponuje się: Za ręke mnie weź, Panie; $W$ droge pokoju oraz Pan mój, Wódz i Pasterz mój, a na zakończenie: Niech dziś z naszych serc. Na powrót pielgrzymów zaleca się nabożeństwo eucharystyczne i odśpiewanie Te Deum. Istotną nowością, której nie spotyka się w innych agendach, jest zaproponowana "modlitwa pielgrzymów w drodze". Ponieważ oddaje ona pątniczego ducha i wskazuje na założony cel, warto ją w całości przytoczyć:

P: Panie, daj nam ducha pielgrzymów, którzy idą, nie przywiązując się do wartości przemijających, którzy idą naprzód bez oglądania się za siebie. Spraw, abyśmy byli prawdziwie wolni, prawdziwie bezinteresowni, prawdziwie wspaniałomyślni. Niech nasz stan pielgrzymi wyciśnie swą pieczęć na całym naszym życiu. Przeszedłszy życie, etap za etapem, niech zachowamy młodość ducha i dojdziemy do kresu przez Ciebie ustalonego, by znaleźć się w boskim sanktuarium pokoju i nieustannej radości, gdy nas wezwiesz do siebie. W: Amen ${ }^{20}$.

Dobór pieśni towarzyszących nabożeństwom świadczy o tym, że przy redagowaniu scenariuszy zostały uwzględnione bogate tradycje i zwyczaje diecezjalne.

\footnotetext{
${ }_{19}$ Agenda liturgiczna, red. H. J. Sobeczko, Opole 2013, s. 558.

${ }^{20}$ Agenda liturgiczna, red. H. J. Sobeczko, s. 560.
} 
Oprócz pielgrzymek parafialnych do różnych sanktuariów, odbywają się pielgrzymki stanowe. Bardzo znana jest np. pielgrzymka mężczyzn do Piekar. Katowicka Agenda liturgiczna proponuje więc nabożeństwo majowe, stosowne na tę okoliczność, odprawiane przed wyruszeniem w drogę. Na wejście pątnicy mogą śpiewać pieśń Matko Piekarska. Po pozdrowieniu wiernych kapłan zwraca się do zebranych, podkreślając rolę matki w rodzinnym domu. Stwierdza, że ludzie tworzą rodzinę Bożą, a Kościół ze swej natury jest „wielką rodziną”. Jej członkowie mają różne potrzeby, a "każdy w innej mierze jest odporny na zło i skłonny do dobra". Matka taką rodzinę scala; rozumie jej członków i jest z nimi w każdy czas. Warto się więc do niej zwracać.

Kolejne części nabożeństwa przeplatane są śpiewem, np. pieśni: Gdy trwoga nas ogarnie i Matko Sprawiedliwości i Miłości Społecznej, módl się za nami, a po wystawieniu Najświętszego Sakramentu: Pójdźcie btogostawić Pana; Pójdźcie wszystkie serca wierne i Maryjo, Tyś nasza nadzieja lub Z śląskich kopalń.

Agenda proponuje też czytanie z Dziejów Apostolskich (Dz 1,1214) i komentarz do niego. $W$ nim na uwagę zasługuje pokazanie Maryi jako Matki Kościoła i Matki ludzi pracy (a dokładniej - górników). Po pieśni Serdeczna Matko wskazane jest odmówić Litanię do Matki Boskiej Piekarskiej, modlitwy z nabożeństwa do Matki Boskiej Piekarskiej lub wezwania do niej (oddanie w opiekę problemów śląskiej ziemi, jej mieszkańców, ojczyzny, archidiecezji, cierpiących, chorych i nieszczęśliwych, ludzi pracy, słabych w wierze, grzeszników, wrogów Kościoła i siebie samych).

W dalszej części przewidziano wystawienie Najświętszego Sakramentu, krótką adorację i błogosławieństwo eucharystyczne albo tylko błogosławieństwo na trud pielgrzymki ${ }^{21}$.

Wszystkie modlitwy proponowane w Agendach liturgicznych na rozpoczęcie i zakończenie pielgrzymki są podobne. W Stowie na droge zawierają polecenie własnych spraw pątników, spraw innych ludzi, Kościoła i świata, błogosławieństwo na czas wewnętrznej odnowy i duchowego odrodzenia oraz szczęśliwy powrót do domu. Często znajduje się tu odniesienie do Rafała Archanioła, by towarzyszył pątnikom w ich drodze.

Wezwanie do Boga (modlitwa) zwykle nawiązuje do wędrówki Izraelitów przez Morze Czerwone, drogi Mędrców do Pana, która prze-

${ }^{21}$ Agenda liturgiczna. Opracowanie zbiorowe Archidiecezjalnej Komisji Liturgicznej, Katowice 2005, s. 268-271. 
biegała pod przewodnictwem gwiazdy oraz podróży młodego Tobiasza w towarzystwie Anioła.

Błogosławieństwo jest raczej standardowe, wyrażone np. słowami: „Pan nasz, Jezus Chrystus, niech będzie przy was, aby was bronić, niech będzie przed wami, aby was prowadzić, niech będzie za wami, aby was strzec, niech będzie z wami, aby was błogosławić. Pokój i błogosławieństwo Boga wszechmogącego, Ojca i Syna, i Ducha Świętego, niech zstąi na was i pozostanie na zawsze"22. Zawsze te trzy elementy: słowo na drogę, modlitwa $\mathrm{w}$ intencji pielgrzymów i ich błogosławieństwo - są „filarami” liturgii na rozpoczęcie pielgrzymki.

Pewien porządek jest też zachowany $\mathrm{w}$ trakcie nabożeństwa po powrocie pielgrzymów. Obejmuje powitanie ich przez kapłana, podziękowanie za pielgrzymi trud i modlitwy zanoszone $\mathrm{w}$ intencji parafii. Następnie odbywa się nabożeństwo eucharystyczne, które można odprawić, chociaż nie jest to wymóg absolutny. Stałymi punktami nabożeństwa są: modlitwa dziękczynna za łaski udzielone podczas pielgrzymki i za szczęśliwy powrót do domu; modlitwa wstawiennicza o trwałość owoców pielgrzymki i prośba o stały dar pokoju i poczucie bezpieczeństwa; Modlitwa Pańska (Ojcze nasz) oraz błogosławieństwo sakramentalne. Wdzięczność względem Boga może być (i często bywa!) wyrażona słowami hymnu: Ciebie, Boga, wystawiamy.

\section{TROSKA KOŚCIOŁA O FORMOWANIE RUCHU PIELGRZYMKOWEGO W ZGODZIE Z JEGO NAUCZANIEM}

Rektorzy sanktuariów ustanawiają normy i udzielają praktycznych wskazówek dla pielgrzymów, mając przy tym na uwadze tradycje lokalne i szczególne wyrazy religijności i pobożności ludowej. Znaleźć je można $\mathrm{w}$ informatorach dotyczących różnych świętych miejsc w Polsce i za granicą oraz $\mathrm{w}$ wydawanych publicznych oświadczeniach.

W przewodniku Na Dróżkach Kalwarii Pacławskiej znajdują się rady dla pielgrzymów ${ }^{23}$. W założeniu są one próbą włączenia się w głos, jaki pielgrzym usłyszał w swojej duszy, zanim podjął decyzję o podróży do sanktuarium. Przypominają, że trzeba w niej kierować się wiarą, a droga do celu powinna być przepełniona duchem modlitwy i ofia-

${ }^{22}$ Agenda liturgiczna, red. H. J. Sobeczko, s. 559.

${ }_{23}$ D. Synowiec, Na Dróżkach Kalwarii Pacławskiej, Kalwaria Pacławska 1983. 
ry. Pobyt $\mathrm{w}$ sanktuarium należy potraktować jako swoiste rekolekcje i „wejście w siebie”, żeby dostrzec dobroć Boga działającego w duszy człowieka.

W celu nawiązania prawdziwej łączności ze Stwórcą powinno się pojednać z Nim w sakramencie pokuty. Czas spowiedzi zależy od pielgrzyma, jednak dobrze byłoby ją odprawić jeszcze przed podjęciem pielgrzymki. Niezależnie od tego, w sanktuarium zawsze jest szczególna ku temu okazja. Ponieważ pielgrzymka to zbliżenie się do Ojca i braci, dobrze jest przed nią pojednać się z bliźnimi. W pielgrzymce towarzyszą sobie nawzajem bracia w Chrystusie. Należy o tym pamiętać, by świadczyć im ewangeliczną dobroć, życzliwość, pomoc w pociągu, autobusie i podczas całej drogi. Wspólnie, modlitwą i śpiewem, w czasie trwania pielgrzymki uwielbia się tego samego Stwórcę i Ojca.

Sporo pielgrzymek to autentyczne spotkanie z cierpiącym Chrystusem. „Nie wolno absolutnie używać alkoholu, biorąc udział w tak wzniosłych tajemnicach. Byłoby dobrze, gdybyśmy w duchu jedności z Chrystusem cierpiącym wyrzekli się palenia papierosów"24 w przewodniku modlitewnym.

Opiekunowie sanktuarium przypominają, że ofiarami są też niewygody związane $\mathrm{z}$ pobytem $\mathrm{w}$ świętym miejscu, a nawet czujność przed złodziejami. Piszą: „Znakiem naszej łączności z Bogiem jest również nasze skromne i kulturalne zachowanie w miejscach, gdzie nocujemy" ${ }^{\prime 25}$. Zachęcają do codziennego korzystania z daru Komunii świętej. Podkreślają, że pięknym zwyczajem jest np. ranne śpiewanie Godzinek o Najświętszej Maryi Pannie.

Jeżeli istnieje taka potrzeba, w sprawie pielgrzymowania do miejsc, przez ludzi uznanych za święte, wypowiadają się biskupi krajowi, a nawet Watykan. Tak się stało w przypadku rzekomych objawień w Medjugorie. Biskupi Jugosławii, poczynając od 1991 roku, wiele razy orzekali, że nie można dowieść, że mamy do czynienia ze zjawiskami nadprzyrodzonymi. Kongregacja Nauki Wiary w 1998 roku stwierdziła, że nie ma zgody na kult w tym miejscu. Dotąd Stolica Apostolska oficjalnie nie uznała objawień i ciągle jest to kwestia otwarta. Biskupi dawnej Jugosławii (obecnie Bośni i Hercegowiny) przyznają jednak, że Medjugorie jest miejscem pobożności maryjnej, dlatego chętni mogą tam pielgrzymować prywatnie. Pielgrzymki oficjalne dotąd są zabronione. W objawienia

\footnotetext{
${ }^{24}$ Tamże, s. 15.

${ }^{25}$ Tamże, s. 18.
} 
w Medjugorie można zatem wierzyć, zachowując jednak roztropność i wsłuchując się w głos Urzędu Nauczycielskiego Kościoła ${ }^{26}$.

Wizjonerzy utrzymują, że ich „spotkania” z Maryją dotąd trwają i zdarzają się poza Medjugorie; są bowiem związane nie z miejscem, ale z nimi. Watykan po raz kolejny ostrzegł przed nimi 23 października 2013 roku. W Internecie zamieszczony został list abpa Gerharda Müllera, prefekta Kongregacji Nauki Wiary, skierowany do biskupów amerykańskich, w którym ostrzega przed planowanymi odwiedzinami Ivana Dragićevicia (jednego z wizjonerów z Medjugorie) niektórych parafii w USA. Podczas spotkań przewidziane było „otrzymanie objawień". List przypomniał, że pozostają w mocy wypowiedzi Konferencji Biskupów Bośni i Hercegowiny na temat tego, co się dzieje w Medjugorie, i w tej sprawie obowiązuje stanowisko Watykanu.

W polskojęzycznym informatorze Witajcie w Medziugorju ${ }^{27}$ powołano się na wypowiedź arcybiskupa zagrzebskiego, kardynała Franjo Kuharicia z 15 sierpnia 1993 roku: „My biskupi, po trzyletnim komisyjnym studium akceptujemy Medziugorje jako miejsce pątnicze, jako sanktuarium, to znaczy, że nie mamy nic przeciwko, jeżeli ktoś czci Matkę Bożą w sposób zgodny z nauką Kościoła i wiarą" ${ }^{\prime 28}$. Autor informatora oświadczył, że pozostaje w zgodzie z dekretem papieża Urbana VIII i zarządzeniami Soboru Watykańskiego II i nie pragnie wyprzedzić osądu Kościoła, któremu w pełni się podporządkowuje. W informatorze zawarł wskazówki dla pielgrzymów i organizatorów oraz wskazówki ogólne dla księży. Wszystkie opierają się na wytycznych, że Kościół powinien zapewnić opiekę duszpasterską pątnikom.

Kancelaria parafialna św. Jakuba w Medjugorie zarezerwowała sobie prawo do oprowadzania grup po miejscach modlitwy (kościół parafialny, teren przykościelny, figura Zmartwychwstałego, Góra Objawień, Kriżevac, Niebieski Krzyż, cmentarz itd.). Jednocześnie przypomina się pielgrzymom, że miejsca modlitwy są przestrzenią ciszy i skupienia. Ze względu na świadomość Bożej obecności, atmosfery nie może burzyć nieodpowiednie zachowanie ani ubiór. Informator zawiera również „wskazówki ogólne dla księży”, a zwłaszcza prośbę, by w pełni stosowali się oni „do przepisów kościelnych, przewidzianych w Kodeksie Prawa Kanonicznego, ogólnych przepisów liturgicznych oraz zarządzeń

\footnotetext{
${ }^{26}$ W. R., Kościót a objawienia w Medjugorie, „Niedziela” 2010, nr 8, s. 10.

${ }_{27}$ M. Šteko, Witajcie w Medziugorju, Medugorje 2010.

${ }^{28}$ Tamże, s. 1.
} 
i przepisów przekazanych ze strony miarodajnych władz kościelnych, związanych z życiem i pracą kapłańską"29. Przypomina, że Mszę Świętą można sprawować jedynie $\mathrm{w}$ miejscach konsekrowanych, oficjalnie do tego przeznaczonych. Zabrania organizowania innego programu modlitewnego niż ten przewidziany na terenie parafii. Zwraca uwagę zwłaszcza na "modlitwy o uzdrowienie" i "modlitwy nad innymi osobami”, które objęte są ścisłymi zarządzeniami kościelnymi.

Kongregacja Kultu Bożego wśród sakramentaliów wymienia błogosławieństwa: pielgrzymów, przed rozpoczęciem podróży (wszak każda pielgrzymka jest podróżą), a także urządzeń i przedmiotów przeznaczonych dla podróżujących. We wprowadzeniu podkreśla się fakt, że pielgrzymki do świętych miejsc i do sanktuariów, bez względu na formę, w jakiej są podejmowane (tradycyjna czy współczesna), mają duże znaczenie duszpasterskie, „ponieważ pobudzają wiernych do nawrócenia, pogłębiają życie chrześcijańskie i wpływają na rozwój działalności apostolskiej"30. Obrzędy mają na celu uwydatnienie i przygotowanie tego, co stanowi istotę chrześcijańskiej pielgrzymki, tzn. jej duchowego charakteru. W księdze Obrzędy błogostawieństw dostosowane do zwyczajów diecezji polskich znajdujemy scenariusz obrzędu połączonego z błogosławieństwem pielgrzymów. Na wstępie proponuje się odśpiewanie Psalmu 122 lub innej odpowiedniej pieśni. Następnie celebrans pozdrawia obecnych albo wypowiada inne słowa wzięte z Pisma Świętego. Przygotowuje wiernych do przyjęcia błogosławieństwa. Mówi o istocie pielgrzymki i jej celu, wskazuje na jej aspekt społeczny. Następnie czyta wybrany tekst Pisma Świętego (np. 2 Kor 5,6b-10; Iz 2,2-5; Łk 2,41-51; Łk 24,13-35; Hbr 10,19-25; 1P 2,4-12). Zależnie od okoliczności można wykonać psalm responsoryjny (Ps 24,1-2.3-4b.5-6 albo Ps. 27,1.4.13-14) lub inną odpowiednią pieśń. Celebrans może do uczestników skierować krótkie przemówienie i wyjaśnić im czytanie biblijne po to, by głębiej zrozumieli znaczenie obrzędu. Następnie powinna się odbyć wspólna modlitwa; wezwania mogą uwzględniać sytuacje pielgrzymów albo szczególne okoliczności. Niezmiernie ważna jest kolejna Modlitwa błogostawieństwa. Po niej celebrans kieruje wezwania do Boga, a wszyscy odpowiadają "amen”. Na koniec można zaśpiewać odpowiednią pieśń. Podobny przebieg ma obrzęd błogosławieństwa pielgrzymów dokonywany po ich powrocie.

29 Tamże, s. 5.

${ }^{30}$ Obrzędy błogostawieństw dostosowane do zwyczajów diecezji polskich, t. 1, Katowice 1994, s. 183. 
Szlachetnym zwyczajem wspominanym w Piśmie Świętym jest prośba o Bożą pomoc ludzi, którzy zamierzają się udać w jakąkolwiek podróż. By ten pobożny zwyczaj zachować, istnieje obrzęd błogosławieństwa zawierający przykład modlitwy z tej okazji. Szafarzem może być kapłan, diakon lub osoba świecka. Każdy, zachowując strukturę i podstawowe elementy obrzędu, powinien dostosować celebrację do sytuacji podróżujących i miejscowych okoliczności. Dla pojedynczych osób lub małych grup proponuje się obrzęd krótszy, dla większych - dłuższy. Każdy rozpoczyna się „W imię Ojca i Syna, i Ducha Świętego” i formułą przygotowania obecnych do przyjęcia błogosławieństwa. Zawiera ona prośbę o wytyczenie podróżnym pomyślnej drogi, doświadczanie gościnności i Bożej dobroci, by mogli chwalić Boga w Jego stworzeniach, głosić ludziom dobrą nowinę o zbawieniu i wyróżniać się uprzejmością, życzliwością i pomocą bliźnim. Słowo Boże może pochodzić z Ewangelii według św. Łukasz (Łk 3,3-6), z Księgi Powtórzonego Prawa (Pwt 6,4-9) lub być innym fragmentem. Zależnie od okoliczności można wykonać psalm responsoryjny (Ps 23,1-2a.2b-3.4.5.6) lub inną pieśń właściwą na tę okoliczność. Od szafarza zależy, czy będzie przemawiał do obecnych. W obrzędzie nie może zabraknąć modlitwy wspólnej, a później modlitwy błogosławieństwa. W niej znajdą się nawiązania do wędrówki Izraelitów przez Morze Czerwone i podróży Mędrców, a wreszcie prośba o wspomożenie braci, pomoc im w szczęśliwym przebyciu drogi i dotarciu do celu doczesnego, a kiedyś - do portu wiecznego zbawienia. Na tym obrzęd może się zakończyć.

Obecnie ludzie znajdują cenną pomoc w urządzeniach i przedmiotach skracających odległość oraz ułatwiających komunikację. Są to: drogi, place, mosty, koleje, różnego rodzaju pojazdy, statki i samoloty. Posługiwanie się nimi pogłębia świadomość wspólnych obowiązków społeczeństwa, stanowi dogodną okazję do uwielbienia Boga i wspólnej modlitwy za tych, którzy z tych urządzeń korzystają.

Zachowując strukturę obrzędu i jego podstawowe elementy, szafarz może wybrać pewne jego części, aby celebrację dostosować do sytuacji osób i miejscowych okoliczności. Rytuał przewiduje obrzęd krótszy i dłuższy. Wprowadzeniem do przyjęcia błogosławieństwa jest przemówienie celebransa podkreślające fakt, że tak jak Chrystus przyszedł na świat, aby rozproszone dzieci Boże zgromadzić w jedno, wszystko, co prowadzi do zjednoczenia ludzi, odpowiada Bożym planom. Wzywa on Boga, aby błogosławił tym, którzy np. zbudowali pojazd, i tym, któ- 
rzy będą z niego korzystać. W strukturze obrzędu występuje czytanie słowa Bożego, np. Ewangelii wg św. Jana (J 14,6-7) albo innego tekstu (np. Dz 17,22-28). Następnie wykonuje się psalm responsoryjny lub inny śpiew. Przed modlitwą błogosławieństwa odmawia się modlitwę wspólną. Błogosławieństwo pojazdu może mieć następującą formułę:

Wszechmogący Boże, Stwórco nieba i ziemi! Ty w swojej niezmierzonej mądrości powierzasz człowiekowi do wykonania piękne i wielkie dzieła. Spraw, niech ci, którzy będą się posługiwać tym pojazdem, sami ostrożnie i bezpiecznie odbywają swoje podróże i roztropnie dbają o bezpieczeństwo innych ludzi. Gdy będą się udawać do pracy lub na odpoczynek, niech w drodze zawsze towarzyszy im Chrystus, który z Tobą żyje i króluje na wieki wieków ${ }^{31}$.

W modlitewniku Pokój wam ${ }^{32}$ znajduje się nawet stosowna modlitwa prowadzącego pojazd mechaniczny. Rozpoczyna się od apostrofy do Boga kierującego całym wszechświatem. Zawiera prośbę o pewne oko i rękę, by nikomu nie wyrządzić szkody na drogach. Kolejna apostrofa do Boga, przestrzegającego praw przez siebie wydanych, uzupełniona jest prośbą o zachowanie przepisów drogowych. Dawca życia nie powinien pozwolić, aby kierowca stał się przyczyną śmierci lub kalectwa innych ludzi oraz osób towarzyszących mu w podróży. Głęboką treść zawierają wezwania: „Naucz mnie używać maszyny, którą prowadzę, tylko dla dobra współbraci i dla dobra wspólnego [...], pohamuj we mnie pokusę pośpiechu i nadmiernych szybkości". Modlitwa kończy się następująco: „Boże, Stworzycielu świata i ludzi, niech piękno stworzonego przez Ciebie świata, życzliwość ludzi i radość Twojej łaski towarzyszą mi zawsze" ${ }^{\prime \prime 3}$.

Z pielgrzymki przywozi się pamiątki: przedmioty, modlitewniki, obrazki, książki. Mają one stanowić przekaz prawdziwego ducha miejsca świętego. By tak się stało, powinny zostać pobłogosławione. Teksty błogosławieństw są zamieszczone w Obrzędach błogosławieństw dostosowanych do zwyczajów diecezji polskich ${ }^{34}$. Również w Agendach liturgicznych znajdują się ich odpowiednie formuły (ad omnia). Zawierają czytanie słowa Bożego (np. 1 Tm 4,4-5 lub 1 Kor 10,31). Zależnie od okoliczności

${ }^{31}$ Obrzędy błogostawieństw..., s. 288-289.

32 T. Bielski, Pokój wam. Modlitewnik, Poznań 1991, s. 326-327.

33 Tamże, s. 326-327.

${ }^{34}$ Obrzędy błogostawieństw..., s. 202-211. 
proponują odmówienie lub odśpiewanie psalmu responsoryjnego albo innej odpowiedniej pieśni. Podpowiedziana modlitwa błogosławieństwa zawiera apostrofę do wszechmocnego, wiecznego Boga, którego wszystkie stworzenia są dobre oraz deklarację wiernych, że przyjmują je z dziękczynieniem. Boże słowo i modlitwa ludzi uświęcają wszystko, stąd prośba o błogosławieństwo przedmiotów, „aby wszyscy, którzy zgodnie z Twoją wolą będą tego używać (lub tym się posługiwać), wzrastali w wierze, a od Ciebie doznawali pomocy i opieki" ${ }^{\prime 35}$. Po pokropieniu przedmiotów wodą święconą $\mathrm{w}$ omawianym rytuale proponuje się adorację Boga. Kapłan odmawia modlitwę na przemian z ludem. Prosi o to, by wszyscy wierni dostrzegali dobro, którym Pan ich obdarza, i szczerym sercem za to Go miłowali. Pokój Boży powinien sprawić, że serca i umysły ludzi pozostaną w stałej jedności z Jezusem Chrystusem.

W omawianej agendzie znajduje się osobne błogosławieństwo modlitewnika. Kapłan prosi Boga, by pobłogosławił i pomnażał wiarę tych, którzy z pomocą modlitewnika będą się do Niego modlić. Poleca ich, by pełnili Boże przykazania, a ich godziwe pragnienia, zgodne z Jego wola, się spełniały. Jak pozostałe przedmioty, także modlitewniki kapłan poświęca wodą święconąi

Także Rytuat rodzinny ${ }^{37}$ zamieszcza błogosławieństwo przed podróżą. Wyjaśnia, że współczesne czasy są charakteryzowane przez wielki ruch ludności. Podróżuje się pieszo, własnymi autami, autobusami, pociągami, statkami i samolotami. Z podróżą przeważnie związany jest trud, niewygody, zmęczenie, a nawet niebezpieczeństwo. Bywa i tak, że dla wielu osób podróż, w jaką wyruszają, staje się ostatnim etapem ich życia. Chrześcijanie doskonale zdają sobie z tego sprawę, pragną więc, aby w czasie podróży był uwielbiony Bóg.

Jeżeli rodzina lub ktoś $\mathrm{z}$ jej członków udaje się w podróż (na pielgrzymkę, ale niekoniecznie na nią), dobrze jest, by wyruszył z błogosławieństwem Bożym. Można go upraszać we wspólnej modlitwie i poprzez czytanie słowa Bożego. W niektórych rodzinach istnieje zwyczaj wybierania dla udającego się w podróż wersetu z Pisma Świętego i przekazania mu go na drogę jako "słowa życia”, do którego będzie powracał w rozważaniach i modlitwach. Może się to stać dla niego zachętą, by Biblię zabrać ze sobą.

\footnotetext{
${ }_{35}$ Agenda liturgiczna, red. H. J. Sobeczko, s. 681-682.

36 Tamże, s. 680.

${ }^{37}$ J. Wysocki, Rytuat rodzinny, Włocławek 2000, s. 544-547.
} 
Szafarzem obrzędu może być kapłan, diakon, rodzice lub inna osoba świecka, odpowiednio do tego przygotowana. Celebracja może mieć wersję dłuższą lub krótszą, zależy to od okoliczności. Dłuższa zawiera przygotowanie wstępne, a w nim wyjaśnienie celu i istoty tego znaku. Czytanie słowa Bożego może pochodzić z Księgi Tobiasza (Tb 5,17b-18a; 21-22) lub z Księgi Powtórzonego Prawa (Pwt 6,4-9). Potem przez pewien czas można zachować milczenie, a następnie $\mathrm{w}$ formie modlitwy powszechnej, własnymi słowami (lub za pomocą podanej formułki), zwrócić się do Boga z prośbami w intencji wyruszających w podróż.

Forma modlitwy błogosławieństwa zależy od tego, kto jest jej szafarzem. Jeżeli jest to kapłan lub diakon, to rozkłada on ręce; jeśli osoba świecka, to ręce składa. Inny jest tekst, jeżeli szafarz również wyrusza w podróż, a inny, kiedy pozostaje. Na zakończenie obrzędu kapłan lub diakon udzielają zwykłego błogosławieństwa, a osoba świecka wzywa Bożego błogosławieństwa dla tych, którzy mają wyruszyć w podróż i wszystkich obecnych. Jeżeli błogosławieństwa wzywają rodzice, na czole udającego się w podróż czynią znak krzyża, a następnie udzielają pocałunku pokoju.

W pielgrzymkę nierzadko wyruszają całe rodziny, tzw. domowy Kościół. Ojciec święty, Jan Paweł II, tę praktykę zalecał rodzinom chrześcijańskim jako jedną z form niedzielnego świętowania, dającą głębsze doświadczenie wiary. Pisał: „Są to chwile przesycone szczególną łaską, którym winna towarzyszyć odpowiednia ewangelizacja i mądre kierownictwo duszpasterskie"38. Autor Rytuatu rodzinnego podpowiada rodzinom, że w czasie pielgrzymki wskazane jest czytanie Pisma Świętego, odmawianie różańca i innych modlitw, śpiew psalmów i pieśni religijnych. Pisze: „Pielgrzymka pomoże rodzinie zrozumieć, «że w istocie życie nasze jest pielgrzymowaniem» do domu Ojca, a także uświadomić istotę Kościoła pielgrzymującego oraz doświadczyć braterstwa, życzliwości i miłości braci w wierze" ${ }^{\prime \prime 39}$.

Przytacza obrzęd nabożeństwa przed rozpoczęciem pielgrzymki. Przewodniczy mu z reguły ojciec lub matka rodziny. Zawiera on wprowadzenie, będące rodzajem modlitwy powszechnej, pozdrowienie i słowo wstępne, które przypomina, czym dla chrześcijanina jest pielgrzymka

${ }^{38}$ List apostolski Dies Domini Ojca Świętego Jana Pawła II o świętowaniu niedzieli, http://www.vatican.va/holy_father/john_paul_ii/apost_letters/documents / hf_jp-ii_apl_05071998_dies-domini_pl.html [dostęp z dnia 16.12.2013].

${ }^{39}$ J. Wysocki, Rytuat rodzinny, s. 549. 
i jaka być powinna. W modlitwie wstępnej, z Maryją i świętymi w niebie oraz duszami czyścowymi, prosi o wstawiennictwo i pomyślność nie tylko dla pielgrzymów, ale całego Kościoła. Jako czytanie biblijne rytuał poleca fragment z Drugiego Listu św. Pawła do Koryntian (2 Kor 5,1-10). Po psalmie responsoryjnym proponuje dominikańską modlitwę błogosławieństwa. Zawiera ona prośbę o pomyślną podróż, czas spokojny i szczęśliwe dotarcie do miejsca świętego, a wreszcie do portu wiecznego zbawienia. Wspomina wędrówkę Izraelitów przez Morze Czerwone, podróż Mędrców do stajenki i wyprowadzenie Abrahama z Chaldejskiego Ur. Wzywa wstawiennictwa anioła Rafaela. Modlitwa zawiera pięknie sformułowaną prośbę: „Bądź nam, Panie, w niebezpieczeństwie pomocą, - $\mathrm{w}$ drodze ulżeniem, - w skwarze ochłoda, $-\mathrm{w}$ deszczu i zimnie okryciem, - $\mathrm{w}$ znużeniu wozem, $-\mathrm{w}$ przeciwnościach obroną, - $\mathrm{w}$ potknięciu laską, - w nawałnicy portem, - abyśmy za Twoją wodzą pomyślnie dotarli tam, dokąd zmierzamy, - a w końcu cało wrócili do domu"40.

Z dokumentów Kościoła dotyczących pielgrzymek wynika, że są one przez tę instytucję uznawane i cenione. Obecnie istnieje nawet potrzeba pielęgnowania i odpowiedniego formowania zróżnicowanej pobożności i religijności ludowej, w tym także takich jej przejawów, jak pielgrzymki. Chodzi jednak o to, żeby wszystko odbywało się w zgodzie z liturgią. W tym obszarze dotąd istnieją jednak zasadnicze braki. Nie ma pielgrzymki jako uroczystości kościelnej, przewidzianej i odnotowanej w mszale. Tego braku nie zastąpią wskazówki oraz zarządzenia i zalecenia biskupów oraz ich bezpośrednich współpracowników, a szczególnie rektorów sanktuariów. Owocna praca duszpasterska wymaga odgórnego uregulowania powyższych kwestii, a zwłaszcza uzupełnienia mszałów.

Nawiązania do pielgrzymek znajdują się w Katechizmie Kościoła Katolickiego, w adhortacjach i listach apostolskich. Celebracje nabożeństw związanych z pielgrzymką znajdują się w Dyrektorium o pobożności ludowej i liturgii, Obrzędach błogosławieństw dostosowanych do zwyczajów diecezji polskich oraz w Rytuale rodzinnym. Stosowne modlitwy z nią związane zamieszczają także Agendy liturgiczne. Niemniej cały zgromadzony na temat materiał, wobec wagi i znaczenia tej formy pobożności, jest niewielki.

Dobrze byłoby, żeby braki jak najszybciej zostały uzupełnione.

40 Tamże, s. 552. 
Streszczenie. Tematem artykułu jest „obecność” pielgrzymek w dokumentach i liturgii Kościoła. Aby problem ten zgłębić, zbadano mszały i stwierdzono brak w nich tych form pobożności jako uroczystości kościelnych. Skupiono się więc na obrzędzie sprawowania liturgii dla grup specjalnych. Dokonano też przeglądu innych dokumentów Kościoła: Katechizmu Kościoła Katolickiego, adhortacji i listów apostolskich. Według nich od duszpasterza zależy wybór Eucharystii i innych nabożeństw. Obrzędy tych ostatnich znajdują się w Dyrektorium o pobożności ludowej i liturgii, Obrzędach błogostawieństw dostosowanych do zwyczajów diecezji polskich, w Rytuale rodzinnym i Agendach liturgicznych. Porównano nabożeństwa proponowane przez agendy, uwzględniające lokalne zwyczaje i szczególne okoliczności pielgrzymek.

Odwołano się do norm, wskazówek praktycznych i rad dla pątników, udzielanych przez rektorów sanktuariów, a nawet Stolicę Apostolską. Stwierdzono, że cały zgromadzony materiał dotyczący pielgrzymek w dokumentach i liturgii Kościoła, wobec wagi i znaczenia tej formy pobożności dla chrześcijańskiego życia i praktykowania wiary, jest skąpy i niewystarczający.

Słowa kluczowe: liturgia pielgrzymki; normy prawne pielgrzymowania; pielgrzymka; rytuał pielgrzymów.

Abstract: Pilgrimages in the documents and the liturgy of the Church. The theme of the article is the "presence" of pilgrimages in the documents and the liturgy of the Church. To explore this issue, the missals were examined and it has been found that there is no form of piety in them. We therefore focused on the rite of the liturgy for special groups. There was a review of other documents of the Church: The Catechism of the Catholic Church, exhortations and apostolic letters. According to them, the choice of the Eucharist or other church services depends on the priest. The rituals of these services are presented in the Directory on Popular Piety and the Liturgy, the Book of Blessings adapted to the customs of the Polish dioceses, in the Family ritual and Liturgical agendas. The devotions proposed by agendas were compared by taking into account local customs and special circumstances of pilgrimages. The reference was made to the laws, practical guidelines and advice for pilgrims, provided by the rectors of sanctuaries, and even the Holy See. It has been concluded that all the gathered material concerning pilgrimages in the documents and the liturgy of the Church is skimpy and insufficient.

Keywords: liturgy of the pilgrimage; laws of pilgrimage; pilgrimage; pilgrim's ritual. 
